\title{
CONTEMPORARY RECEPTION OF GNOSIS IN POLAND: JERZY PROKOPIUK AND THE QUEST FOR SPIRITUALITY
}

ABSTRACT. Artur Jocz, Contemporary reception of gnosis in Poland: Jerzy Prokopiuk and the quest for spirituality, edited by Z. Drozdowicz and S. Sztajer, "Człowiek i Społeczeństwo" vol. XLI, Poznań 2016, pp. 247-254, Adam Mickiewicz University Press. ISSN 0239-3271.

While discussing gnosis in contemporary Polish culture, it is impossible to overlook the figure of Jerzy Prokopiuk (born 1931). But Prokopiuk's body of work should not be judged solely on the merit of his prolific publishing and popularising activity, as one should also take into consideration his spiritual, intellectual and gnostic explorations, as well as how they contributed to the historical reception of gnostic ideas in Poland. This is why this paper will seek to present Prokopiuk's views on the essence of God, the nature of the world, and the human phenomenon.

Artur Jocz, Adam Mickiewicz University in Poznań, Department of Religious and Comparative Studies, ul. Szamarzewskiego 89ab, 60-568 Poznań, Poland, e-mail: jocz@neostrada.pl

While discussing gnosis ${ }^{1}$ in contemporary Polish culture it is impossible to overlook the figure of Jerzy Prokopiuk (born 1931) and his legacy constituting an enormous translation output - with some 124 published

${ }^{1}$ For more on Gnosis and Gnosticism see, for example, H. Jonas, The Gnostic Religion, Beacon Press, Boston 2001; W. Myszor, Gnostycyzm - przegląd publikacji, "Studia Theologica Varsaviensia” 1/1971, pp. 367-424; J. Prokopiuk, Gnoza i gnostycyzm, Typograficzna Oficyna Wydawnicza Firet \& Antykwariat Daimonion, Warszawa 1998; J. Prokopiuk, Labirynty herezji, Muza, Warszawa 1999; G. Quispel, Gnosis als Weltreligion, Origo Verlag, Zürich 1951; H. Rousseau, Le Dieu du mal, Presses Universitaires de France, Paris 1963. 
translations including the works of Karl Gustav Jung (1875-1961), Rudolf Steiner (1861-1925), Meister Eckhart (1260-ca. 1328), Angelus Silesius (1624-1677), a great variety of other gnostic sympathisers, and some other thinkers such as, for example, Max Weber. ${ }^{2}$ However, Prokopiuk's body of work should not be judged solely on the merit of his prolific publishing and popularising activity, ${ }^{3}$ as one should also take into consideration his spiritual, intellectual and gnostic explorations, as well as how these contributed to the historical reception of gnostic ideas in Poland. This paper will seek to present Prokopiuk's views on the essence of God, the nature of the world, and the human phenomenon.

Presenting his idea of the Absolute, the thinker/gnostic tries to make a distinction between some sort of a deep structure of an Ideal Being and its surface responsible for creating a sensible reality, ${ }^{4}$ in doing so claiming to be inspired by ideas originating with early Christian Gnosticism, the teachings of Meister Eckhart (1260-ca. 1328), and Jacob Böhme (15751624). He therefore envisages a God that is essentially distant from human, anthropomorphic representations. Let us bear in mind that this approach to the Absolute has long traditions in Polish culture, as evidenced, for example, by critical studies authored by Stanisław Przybyszewski (1868-1927), who explored the spiritual aspects of writings left by Juliusz Słowacki (18091849). ${ }^{5}$ The matter in question was also studied by Nikolai Berdyaev (18741948). The Russian philosopher argued that the rationalisation of Orthodox Christianity made it impossible for believers to come closer to the essence of God, believing, however, as he did, that a man formed by purely rational cognition somewhat instinctively opens up to "the light perceived by reason, instead of a mysterious abyss that creates for reason nothing but antinomies." ${ }^{\prime 6}$ It is therefore natural for human reason to see its own semblance in the Absolute. It must be noted, however, that Prokopiuk is not satisfied with this liberation from anthropomorphic constraints, arguing, for example:

${ }^{2}$ Prokopiuk's translations to Polish include for example, C.G. Jung, Answer to Job; R. Steiner, The Philosophy of Freedom: The Basis for a Modern World Conception; Meister Eckhart, Sermons and Treatises; Angelus Silesius, The Cherubinic Wanderer; M. Weber, The Sociology of Religion.

3 See, for example, the gnosis issue of "Literatura na Świecie," December 1987, and the periodical "Gnosis," appearing on paper between 1991-2000.

${ }^{4}$ See J. Prokopiuk, Rozdroża, czyli zwierzenia gnostyka, Katowice 2004, pp. 176-179.

5 See S. Przybyszewski, Ekspresjonizm - Słowacki i “Genezis z Ducha," “Zdrój” 1918, vol. 1, pp. 5-7, vol. 2, pp. 36-39, vol. 3, pp. 66-68, vol. 4, pp. 99-101, vol. 5, pp. 132-134, vol. 6, pp. 164-169.

${ }^{6}$ M. Bierdiajew, Sens twórczości. Próba usprawiedliwienia człowieka, transl. H. Paprocki, Antyk, Kęty 2001, p. 108. 
The Highest God simultaneously reconciles oppositions as a Being and a Non-Being. [...] If we were to look for the closest image representing God, it would be a Tree, both a Tree of Life and a Tree of Knowledge, a Tree that branches out into eternity and a "space" of some sort. As such, it brings to life enormous, that is, infinite, numbers of Demiurges, Gods of Cosmic Worlds. These Cosmic Worlds further branch off into numerous alternative Cosmic Worlds. ${ }^{7}$

What strikes the reader in this visualisation is not merely what appears to be the boundless creative potency of the Ideal Being, but first and foremost "its" eagerness to share it with lesser demiurgic beings. And so it is the latter who ultimately manifest as the surface of God who, by creating his own world, takes part in the creative freedom of the Absolute. These demiurgic beings enjoy an ontological warranty for particular cosmic worlds since the creative/constructive freedom of Demiurges is not bound in any way - not even by the will of the deep structure of the Ideal Being - which is why they are unceremoniously making use of the potency to create virtually infinite numbers of possible worlds. This sometimes leads to realities that are quite simply botched - which brings Prokopiuk to his gnostic, which is to say depreciatory, perception of the surrounding material reality. Describing the world he lives in, the thinker turns to the gnostic tale of the Demiurge - Yahveh. Again, this is a familiar concept in Polish culture, with some artists, among them the aforementioned Stanisław Przybyszewski, exploring the idea in their work. ${ }^{8}$ However, while offering his gnostic critique of the creation of Yahveh, Prokopiuk first and foremost takes issue with the fact that "both evil and suffering in this world is maximised, not minimised $[\ldots], " 9$ arguing that this surplus of pain comes with no rational justification. This shape of human, material existence, is in his view unacceptable for a human being, and should encourage him to think of Yahveh with moral condemnation. Attempting to fathom the unbearable quality of life in a world of the senses, the thinker turns to the Neognostic thought of Rudolf Steiner. According to the anthroposophist, ${ }^{10}$ suffering was purposefully included in the design of the physical world, and should encourage human beings to try

7 J. Prokopiuk, Rozdroża..., p. 177.

${ }^{8}$ See A. Jocz, Przypadek “osy rozbójniczej.” Rozważania o gnostycyzmie i neognozie w literaturze polskiej przełomu XIX i XX wieku, Poznań 2009, pp. 21-34.

9 J. Prokopiuk, Rozdroża..., p. 180.

${ }^{10}$ On the idea of anthroposophy as Neognosis, see J. Prokopiuk, Antropozofia, czyli wiedza duchowa, in idem, Labirynty..., pp. 89-233; J. Prokopiuk, Gnoza, gnostycyzm, neognostycyzm, in idem, Ścieżki wtajemniczenia. Gnosis aeterna, Warszawa 2000, pp. 132137; A. Jocz, Antropozofia Rudolfa Steinera (1861-1925), czyli próba stworzenia podstaw neognozy, in E. Przybył (ed.), Oblicza gnozy, Nomos, Kraków 2000, pp. 97-112. 
to overcome it. ${ }^{11}$ Commenting on this suggestion, Prokopiuk points out that "very often, all too often, I would say, we are not able to overpower evil nor transform it into good," 12 which is why at times he feels compelled to agree with the early Christian Gnostics who argued that universal suffering signifies creational failings on the part of the Demiurge - Yahveh. He does so not only to show his sympathies for Gnostic teaching, but also to manifest his objection against demiurgic creation, which promises a cosmos (a world of order), but all it is able to deliver is the chaos of a wholly unreasonable and universal pain. Trying to clarify what stands behind this refusal to accept the surrounding reality, Prokopiuk suggests that it comes as a result of a Gnostic calling that reaches him, and other human beings, from the depth of the Ideal Being, thus giving humanity a hope for liberation from the shackles of the material world. ${ }^{13}$ With this statement Prokopiuk wholly and openly embraces the Gnostic quest for redemptive gnosis/knowledge. But does it bring hope as much as one would anticipate? The answer to this question is not necessarily as simple as one would tend to think.

First and foremost, the thinker somewhat cheekily suggests that his own individual existence has already progressed towards highly advanced actualisation, which is to say that he is in a natural way exposed to the irreversible passage of time. ${ }^{14}$ At the same time, however, he still lives with the Gnostic awareness of being thrown into the physical world that has disappointed his expectations. Having studied Gnosis, Prokopiuk is naturally aware that Gnostic tradition knows how to overcome the matter which holds sway over human beings. Prokopiuk mentions, among others, the Luciferic negation of sensible reality, and the Ahrimanic temptation to rebel against the fundaments of the Cosmos founded by the Demiurge - Yahveh. With this view, he subscribes to the anthroposophic view on the spiritual/demonic inspiration of human action. ${ }^{15}$ Another alternative for transcending this demiurgically determined world is the trans-spiritualisation of physical reality proposed by Rudolf Steiner, the founder of anthroposophy. Arguing that "sense-percep-

11 See J. Prokopiuk, Rozdroża..., pp. 180-181.

12 Ibidem, p. 181.

${ }^{13}$ For the idea of Gnostic calling see, for example, A. Jocz, Rozum Arystotelesa a gnostyczne po- “wołanie.” Dwa różne poczq̨tki poznawania istoty Absolutu, "Poznańskie Studia Polonistyczne” 2001, Seria Literacka, no. VIII (XXVIII), pp. 71-86.

${ }^{14}$ See Przemieniać siebie, innych i Ziemię, Jerzy Prokopiuk in conversation with Zbigniew Bierzański, in J. Prokopiuk, Labirynty..., p. 269.

${ }^{15}$ For anthroposophic demonology, see J. Prokopiuk, Steinerowska demonozofia, in idem, Ścieżki wtajemniczenia..., pp. 80-91; A. Jocz, Bóg mistyków a szatan gnostyków. Miejsce zła w antropozoficznej neognozie, “Człowiek i Społeczeństwo” vol. XX, ed. by Z. Drozdowicz, Poznań 2002, pp. 85-99. 
tible things are nothing else than condensed spirit beings," ${ }^{16}$ Steiner means that the world was originally of a spiritual nature, achieving its material shape only later in time. He further argues that the reality surrounding human beings should not be perceived in terms of the dualistic tension between spirituality and materiality, ${ }^{17}$ claiming that also the human, sensible body is part of this spiritual/material world because it was formed as an effect of the "condensing" of pneumatic reality. For these reasons, the physical world is not an evolutionary culmination of "spirit beings," but rather its transitory stage. The actual destiny of the world and man is to return to their original, which is to say their spiritual, state. Trying to explain the nature of the process he has in mind, Steiner writes:

Thus it is man himself who will bring about the future form of his body. Inasmuch as the human being becomes softer and softer, inasmuch as he separates himself from the hard parts, he is approaching his future. ${ }^{18}$

This passage seems to suggest that this anthroposophic process of trans-spiritualisation material reality evolves over centuries. Steiner continues these Neognostic reflections in his Theosophy of the Rosicrucian by offering further remarks on human sexuality and procreation, envisaging this in the following way:

Above all it will be upon the reproductive force that man will work [...]. The generative process and all that stands in connection with it will pass over in the future to another organ. The organ that is already preparing to become the future organ of generation is the human larynx. Today it can only bring forth vibrations of the air, can only impart to the air what lies in the word that goes forth from it, so that the vibrations correspond to the word. Later on, not only will the word press forward in its rhythm from the larynx, but it will be irradiated by man, it will be penetrated by very substance. Just as today the word only becomes airwaves, so in the future man's inner being, his own likeness, which today is in his word, will issue from the larynx. The human being will proceed from the human being, man will speak forth man. And this in the future will be the birth of a new human being - that he is spoken forth by another. ${ }^{19}$

${ }^{16}$ R. Steiner, Theosophy. An Introduction to the Spiritual Processes in Human Life and in the Cosmos, transl. C.E. Creeger, Anthroposophic Press, New York 1994, p. 149.

${ }^{17}$ See R. Steiner, Posłannictwo Archanioła Michała, transl. E.M. Waśniewscy, Genesis, Gdynia 2001, p. 102.

${ }^{18}$ R. Steiner, Teozofia Różokrzyżowców, transl. M. Waśniewski, Genesis, Gdynia 1996, s. 123.

19 Ibidem. 
This stunning description of the birth of a new man may be for a contemporary rationally-minded reader rather difficult to accept. Why, then, is Prokopiuk so eager to embrace it? ${ }^{20}$ Does it come as an effect of the Neognostic fascinations nurtured by this Polish scholar of gnosis thought? Trying to grasp why Prokopiuk takes the above visualisation so seriously, it may be instructive to reiterate Steiner's reflections on the spiritualisation of the physical world, where he argues that the human body is destined to progress towards perfection, achieving gradual liberation from material constraints as it evolves towards spirituality. The destiny of man, therefore, is to set himself free from physicality, thus paving the way to "speaking forth" another human being. This anthroposophic transformation of human corporeality is clearly a somewhat modified version of the Docetism proposed by early Christian Gnostics. Let us bear in mind that this Docetistic perception of the body was popular even among some of the Christian scholars who took care to keep their thinking in line with official doctrine. This is most notably the case of the reflections on the non-affective nature of the body of Jesus Christ authored by Clement of Alexandria (ca.150-ca.215), ${ }^{21}$ although one may of course suggest that this sort of anti-materialistic fascinations corresponded well with the spiritual climate of this time and age. Why, therefore, does applauding the dematerialisation of the human body remain attractive in today's world, particularly if one knows that the sensual, carnal dimension of humanity has reached in the present day its deification? Prokopiuk is perfectly aware, however, that this elevation of the body is happening far away from the suffering, the sick, and the old, who fully experience the countless limitations of material existence. Perhaps this is the reason why this Polish interpreter of gnosis is so invested and finds comfort in the idea of alternative worlds. As one reads his reflections on this particular subject matter, one may come to the conclusion that it contains a Gnosis of reality which actually does exist, but independently from our arduous and physically constraining world. Prokopiuk traces its origins back to the ontologically unbound creativity of the Ideal Being, which never ceases in its divine creations ${ }^{22}$ - which is why the thinker raises the prospect of coming into existence/an existence of a world formed by a Demiurge other than Yahveh. Putting his trust in the imaginative/representational skills of

${ }^{20}$ See J. Prokopiuk, Rozdroża..., p. 146.

${ }^{21}$ For more see K. Aleksandryjski, Kobierce zapisków filozoficznych dotyczq̨cych prawdziwej wiedzy (VI, IX), t. 2, transl. J. Niemirska-Pliszczyńska, Pax, Warszawa 1994, p. 153.

${ }^{22}$ See J. Prokopiuk, Światy alternatywne, in: idem, Ścieżki wtajemniczenia..., p. 217. 
human beings, he is confident that some aspects of this reality are cognizable, promoting his idea of cognition based on gnostic trans-rationalism, which seeks to "transcend rationalism as a one-sided phenomenon," ${ }^{23}$ whilst making it clear, however, that irrationalism is not what he has in mind. He is confident that practicing anthroposophic Neognosis will help man fully actualise his imaginative potencies, which tend to be "incorrectly described as intuition." ${ }^{24}$ Prokopiuk believes that it is precisely this kind of cognition of reality that is prevailing in the alternative world, at the same time indirectly suggesting that he has fully actualised his imaginative potencies. Does it mean that direct cognition of this kind of reality is possible? Furthermore, the Polish gnostic claims that this reality "heads towards the minimization of evil, as opposed to its maximization, which happens to be the case in our world." ${ }^{25}$ Continuing his reflections on alternative realities, Prokopiuk intellectually/spiritually tests the possibility of a world that is free of an unjustified surplus of evil and suffering. But since it is the material body that is most susceptible to pain, striving towards spiritualisation would be a necessary condition for such a reality. Turning to the possibility of accessing such alternative worlds, Prokopiuk somewhat cheekily suggests that he would like to find himself in his new reality following his death, ${ }^{26}$ which is to say that he treats his life in a world designed by the Demiurge in a purely Gnostic way, as a preparation for liberation through death. This is why he sounds rather disturbing when he suggests that the material world is nothing but a large arena where people play out their tragic/comic roles as the Demiurge watches on as the sole spectator. ${ }^{27}$ This highly dramatic conclusion regarding the human condition happens also to be a familiar literary theme, hyperbolised, for example, in an artistic vision proposed by a contemporary Polish writer, Adam Wiśniewski-Snerg (1937-1995), in his novel Według łotra [According to the Rascal]. The following passage serves well to illustrate the reality created by the writer:

That day right from the dawn I had the impression that my surroundings impalpably changed during the night. [...] In the morning I would never lift the window blind. Only when I reached the bathroom I switched on the

${ }^{23}$ Wolę szaleństwo od ślepoty, Jerzy Prokopiuki in conversation with Bolesław Rok, in J. Prokopiuk, Labirynty..., p. 282.

${ }^{24}$ Ibidem, p. 283.

25 J. Prokopiuk, Rozdroża..., p. 147.

${ }^{26}$ See J. Prokopiuk, Gnoza i ja - raz jeszcze, in Mel vitae. Miód życia (a book for the $75^{\text {th }}$ anniversary of Jerzy Prokopiuk), Akasha, Kraków 2010, p. 92.

${ }^{27}$ See ibidem for more on the subject. 
light, stopping helplessly in front of the shelf with toiletries. A thick tube of toothpaste was filled with compressed air. A cube of pink soap fell out my hand and broke at the bottom of the bathtub into several pieces of white plaster. Where the towel once was there was a sky-blue sheet of paper of the same size. Only no water in the tap could be easily explained by the morning spike in consumption. ${ }^{28}$

As he follows the plot, a confused reader learns how waking up in an alternative world may look. It turns out that the protagonist actually lives in a massive movie set. Following his gnostic awakening, the protagonist begins to see that many of the mundane objects around him are just props, while his former friends turn out to be dummies that have replaced extras for economic reasons. We may therefore risk a conclusion that alternative realities are not always the cure for the suffering that engulfs our world.

\footnotetext{
${ }^{28}$ A. Wiśniewski-Snerg, Według łotra, Wyd. Literackie, Kraków - Wrocław 1983, p. 5.
} 